\title{
UREMIC BLEEDING: A CONCISE REVIEW
}

\author{
ÜREMIKK KANAMA: KISA BİR İNCELEME
}

Şinasi SALMAN

SUMMARY

Almost all uremic patients have a bleeding diathesis which becomes a problem during invasive procedures such as surgery, biopsy and catheter placement. Intracranial bleeding, per-m icardial tamponade and gastrointestinal bleeding are the other life threatening clinical presentations. Pathogenesis of uremic hemorrhagic diathesis is not totally clear. A complex platelet dysfunction with abnormal platelet vessel wall interaction is claimed to be the main cause. Uremic toxins are shown to be responsible. Adequate dialysis may correct prolonged bleeding time, but fails at times. The incidence of uremic bleeding has been reduced by kidney transplantation, better management of anemia with recombinant human erythropoietin, and the use of desmopressin (DDAVP), cryoprecipitate, conjugated estrogens. In this article underlying pathophysiology; prophylactic and therapeutic approaches are reviewed.

(Key Words: Hemorrhagic diathesis, Renal Insufficiency, Thrombocytopathy)

\section{ÖZET}

Tüm üremik hastalarda cerrahi, biyopsi ve kateter yerleştirme gibi invaziv uygulamalarda problem yaratabilecek kanama eğilimi vardir.

Üremik Hastalarda kafa içi kanama, perikard tamponadı ve gastrointestinal kanama yaşamı tehdit eden tabloların başında gelmektedir.

Üremik hemorajik diyatezin patogenezi bilinmemektedir. Ana neden olarak trombosit disfonksiyonu ile' trombosit-damar duvarı ilişkilerindeki bozukluklar düşünülmektedir. Üremik toksinler sorumlu tutulmuştur. Yeterli diyaliz uzamış kanama zamanını kısaltabilmektedir.

Böbrek nakli, rekombinan insan eritropoentin'iyle anemiyi giderme, desmopressin (DDAVP), Kryopresipitat ve konjüge östrojen kullanımıla üremik kanama siklığ1 azaltılabilmektedir.

(Anahtar Sözcükler: Böbrek Yetmezliği, Kanama Eğilimi, Trombositopati)

\footnotetext{
Nephrology Unit, (Ş Salman M.D Fellow and

Instructor in Medicine )

University of Rochester Medical Center

Rochester USA
}

Yazışma: 9 Eylül Tıp Fakültesi

Dahiliye ABD-IZMIR 
Many of the clinical presentation of uremic bleeding pose life threatening conditions (Table 1). An occult massive bleeding

TABLE 1. Various clinical presentations of uremic bleeding $(3,10)$

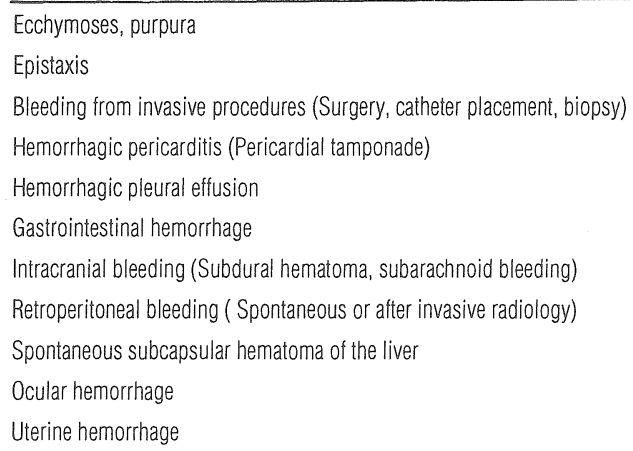

such as pericardial tamponade or gastrointestinal bleeding should be ruled out in a hemodynamicaly unstable uremic patient. Manifestations can be severe in patients with intracranial bleeding and gastrointestinal bleeding (1). Subdural hematoma may mimic dialysis disequilibrium syndrome (2). Gastrointestinal bleeding occurs with greater frequency and is associated with a higher mortality in patients with renal failure than in the general population, and upper gastrointestinal hemorrhage is the second leading cause of death in acute renal failure. (3)

\section{PATHOPHYSIOLOGY OF UREMIC BLEEDING}

The normal physiologic response to the vessel injury begins with local vasoconstriction. Primary hemostasis requires three critical steps: 1. Platelet adhesion, 2. Granule release, 3. Platelet aggregation (4). In the first step endothelial cells secrete von Willebrand factor (vWF) which binds to subendothelial structures and platelet GRIb receptor molecules; by this way platelets are attached to the sites of endothelial disruption. In the second step platelet adhesion triggers release of various mediators such as ADP and TxA2 which stimulate further aggregation and vasoconstriction. Fibrinogen binds platelets to each other, but activation of platelet GPIIb-IIIa receptor molecule is essential for this binding and also to support irreversible adhesion to surface bound vWF (5). Finally platelet interaction with coagulation factors leads to generation of thrombin which activates fibrinogen to form fibrin and thus stabilize fibrin clots (6).

Platelet dysfunction of uremia is multifaceted (Table 2). Platelet count is usually TABLE 2. Factors involved in uremic bleeding diathesis. $(2,3,5,7,8,10,16)$.

\begin{tabular}{l}
\hline Factors related to vessel wall \\
Enhanced prostacyclin production \\
Enhanced nitric oxide production \\
Decreased production of largest vWF multimers \\
Factors related to platelets \\
Low levels of serotonin and ADP \\
High levels of cAMP \\
Defective cyclooxygenase activity (reduced ability to generate thromboxan \\
A2) Abnormal mobilization of platelet Ca \\
Defective activation of GPIIb-IIla receptors \\
Factors related to blood \\
Anemia \\
Altered blood rheology (deranged redial transport of platelets) \\
Altered ADP transfer from erythrocytes to platelets \\
Uremic toxins (guanidinosuccinic acid, phenol, phenolic acid, urea, etc.)
\end{tabular}

normal or slightly low. It has been suggested that uremic patients have a complex platelet dysfunction and an abnormal platelet- vessel wall interaction. Radio- ligand studies indicate an impaired binding of fibrinogen to adenosine diphosphate (ADP) stimulated uremic platelets (7). In particular the ability of the vessel wall to generate a potent antiaggregatory substance, prostacyclin (PGI) increasses in uremia and also endothelial cells seem to generate an abnormal factor VIII/vWF. The largest vWF- pollymers, which are primarily responsible for adhesion process is found to be deficient in uremic patients although serum vWF level is usually high or normal. furthermore, some studies demonstrated a defective interaction of von Willebrand factor to glycoprotein IIg-IIIa responsible for a reduced 
spreading of uremic platelets adhering to subendothelium $(5,7,8)$. Platelets from uremic patients show abnormal adhesive function, a reduced aggregating response to ADP, epinephrin and collagen; and an altered arachidonic acid metabolism. Numer ous biochemical changes in platelets have been reported,including reduction in serotonin and ADP, elevation of cyclic AMP and a reduced ability to generate thromboxane $\mathrm{A}_{\mathrm{g}}$. Anemia causes bleeding tendency probably due to deranged radial transport of platelats, decreasing their contact with the endothelium $(9,10)$. Blood loses from gastrointestinal tract, menstrual blood loses, blood draws during dialysis and blood losses in the dialyzers after each treatment amounts to around 2.5 liters of blood per year for an average dialysis patient (2). This figure does not include occasional large losses caused by surgical procedures or bleeding from access devices. Recent studies suggested that abnormal production of nitric oxide (NO) is also involved in uremic bleeding tendency. $(3,10,11)$. A specific inhibitor of nitric oxide formation, L - NMMA (N - monomethyl - Larginine) completely normalized the prolonged bleeding time of uremic rats $(10,11)$. $\mathrm{NO}$ is a potent vascular relaxing factor and it may to some extent counter the vasoconstriction that follows vessel injury (3). NO also is shown to inhibit the platelet adhesion to vascular endothelium by elevating intracellular cyclic GMP. Some evidence was obtained that white blood cells might also play a role in blood coagulation; white cells have the property to express different types of clot-promoting activites, the so-called procoagulant activity (12). The hemostatic defect appears to be caused, at least in part, by dialyzable uremic toxins, since dialysis transiently improves or even completely corrects the prolonged bleeding time and the clinical bleeding tendency. Urea, creatinine, guanidinosuccinic acid, phenolic acid, and parathyroid hormone have been studied. Various dialyzable toxins and high circulating levels of parathyroid hormone have all been cau- sally related to uremic platelet dysfunction. Dialysis may also contribute to the uremic bleeding tendency. The interaction between blood and artificial surfaces may induce chronic activation of platelets, leading to their dysfunction (10). Heparin, used to obtain systemic anticoagulation, in a minority of patients can induce platelet activation and thrombocytopenia (10). This picture is called heparin associated thromboembolism or white clot syndrome (13).

\section{DIAGNOSIS OF UREMIC BLEEDING}

Various tests have been used to assess the bleeding tendency in patients with uremia, but only the bleeding time has been useful in separating bleeders from nonbleeders $(9,14)$. Although it is a highly valuable laboratory test, the bleeding time is prone to give both falsely abnormal or falsely normal results when performed with improper technique (15). When BUN is greater than 60 $\mathrm{mg} / \mathrm{dl}$, or creatinine greater than $6.7 \mathrm{mg} / \mathrm{dl}$ bleeding time is significantly prolonged (16). Sometimes prolongation of bleeding time may nat be due to uremia it self. For example high doses of penicillins, cephalosporins and related antibiotics, including penicillin G, carbenicillin, ticarcillin, ampicillin and moxalactam, cause prolongation of bleeding time and interfere with platelet function by binding to platelets and blocking recognition of platelet membrane agonist receptors (16). Propranolol and other B-adrenergic blockers induce a mild qualitative platelet defect in some patients by unknown mechanism. Alcohol, which by itself does not affect the bleeding time, enhances the effect of aspirin an prolongation of bleeding time (15). Aspirin's damage to the platelets is irreversible: It inactivates the cyclooxygenase enzyme in the platelets don't carry necessary organelles and nuclear information they can not regenerate this enzyme and prolonged bleeding time usually persists for to 10 days which is roughly equal to the life of a thrnombocyte in the circulation. DDAVP (Desmopressin) can reverse this as- 
pirin effect (6). Non steroid antiinflammatory medications also may cause platelet dysfunction and the duration of this dysfunction is related to the half-life of the medication in the serum.

\section{PREVENTION OF UREMIC BLEEDING}

It is safer to prevent uremic bleeding than to treat. A complete set of coagulation profile including bleeding time should be obtained before any invasive procedure. Bleeding tendencies due to hepatic failure or other causes should also be corrected. If bleeding time is prolonged it should be corrected with DDAVP before the invasive procedure especially in high risk patients. Physicians should be selective about the type and technique of the surgical procedure to minimize the surgical trauma. In the process of a line placement lateral searching movements under the skin with a trochar needle should be avoided, because this action may readily cause rupture of many small subcutaneous venules. Patients undergoing elective surgery should be advised to avoid aspirin and nonsteroid anti inflammatory medications for at least one week prior to operation (15). Adequacy of renal replacement therapy should be checked. Patients who don't receive adequate dialysis tend to bleed more. Patients should get good dialysis before surgery preferably without heparin. Heparin anticoagulation with protamin reversal, minimal heparin, use of prostacyclin, regional citrate anticoagulation are the alternative methods during dialysis. If heparin is used the surgeon should be informed about its dosage and the time given. Even regional heparinization is used rebound heparin effect should be expected during surgery (2). Before surgery a threshold of hematocrit between 27 and $32 \%$ has to be reached for bleeding time to become normal or nearly normal. Autologous blood storage for possible autotransfusion during perioperative period should be considered especially for patients who are transplant candi- dates to avoid sensitization and infectious risks. Dialysis patients usually get rcombinant human erythropoietin (rhEPO) therapy and tend to have iron defiiency due to high rate of iron utilization, so iron stores should be checked and replaced if needed. Patients who are getting erythropoietin treatment and maintaining relatively normal hematocrit levels usually do not have bleeding problems during perioperative period. Invasive procedures in infected areas should be avoided, because infection increasese bleeding tendency, and it is very hard to control bleeding in an infected area until infection is eliminated. Sticking to aseptic technique will eliminate infective complications and the necessityl for antibiotic treatment which may also cause platelet and vascular dysfunctions. If a patient gets a good native arteriovenous fistula at the beginning, many complications from further access placement procedures will be avoided. Synthetic grafts as dialysis access are more prone to thrombosis and infection; their lives are shorter than native fistulas, thus number of access procedures is much higher in these patients.

\section{TREATMENT OF UREMIC BLEEDING}

MECHANICAL PRESSURE: For overt bleeding sites simply prolonged mechanical pressure over the bleeding area may suffice to control bleeding if time is not to prolonged. Catheters involved should not be removed because this may result in a big hole for the blood to extravasate easily and the patient loses vascular access for dialysis. The dressings soaked with blood can be weighted to asses the amount of bleeding. Heparin should be avoided during dialysis until after bleeding stops.

ADEQUATE DIALYSIS: Dialysis has been the standard therapy for uremic bleeding, but it may not be adequate to correct bleeding time (14). Hemodialysis corrects prolonged bleeding time in only $30 \%$ to 50 $\%$ of the cases (6). Peritoneal dialysis patients have fewer bleeding problems $(6,16)$.

ANEMIA: If present, anemia should be 
corrected. As bleeding continues, worsening anemia contributes to the current bleeding tendency. In acute setting packed red blood cell transfusions may be needed to correct anemia. The risk associated with transfusions is not small. Blood or blood product transfusions may cause (I) transmission of viral infections, (II) formation of coagulation factor inhibitors, 1 immune complexes, and (III) anaphylaxis due to IgA deficiency (6). On long term basis recombinant human erythropoietin (rhEPO) 35 to 50 units per kilogram intravenously, three times per week is the current choice of treatment for uremic anemia (16).

DDAVP (Desmopressin: 1-deamino-8-Darginine vasopressin): Desmopressin normalized bleeding time in $75 \%$ of patients with chronic renal failure (6). Recently, under appropriate laboratory conditions, the largest multimeric form of VWF was investigated and found to be reduced or absent in the plasma of patients with uremia and the intraplatelet vWF content was half normal . These windings may explain the beneficial effect of therapeutic agent that either replace or stimulate the release of the large vWF multimers. Desmopressin increases factor VIII and VWF in e dose dependent manner (6). It increases the "largest vWF" polymers in the blood. It also increases plasminogen activator level. Other hemostatic factors are not affected. The peak response of factor VIII occurs almost immediately after the infusion; vWF reaches its peak 30-60 minutes later (6). The exact mechanisms involved in increasing levels of factor VIII, VWF and plasminogen activator are not clear; antidiuretic vasopressin (V2) receptors are thought to be involved. This drug produces little or no vasoconstriction, no increase in blood pressure and no contractions of the uterus or gastrointestinal tract, all of which are related to stimulation of $\mathrm{V} 1$ receptors. Recently a further reduction in protein $C$ activity was shown after the infusion of DDAVP, but the role of this change in the correction of the uremic bleeding is not clear (17).
DDAVP can be administered 0.3 microgram per kilogram intravenously or subcutaneously; 30 microgram per kilogram intranasally. Intravenous route is probably preferable when marked and consistent rise in factor VIII/vWF is required for prophylaxis or treatment of severe hemorrhage. It is usually infused in $50 \mathrm{ml}$ normal saline over 30 minute period. Subcutaneous use gives comparable results, however at least $6 \mathrm{ml}$ of fluid is required to deliver an adult dose of DDAVP by this route. Bleeding time shortens considerably in 2-4 hours, and the effect disappears within 6-8 hours. Although DDAVP can obviate the need for blood products in many of uremic patients, its hemostatic actions tend to be short-lived. DDAVP when used every 12 hours, as usually recommended, may cause tachyphylaxis (6). Initial response is restored when therapy is withheld for three or four days. Since most bleeding episodes and minor surgical procedures require only one or a few doses, tachyphylaxis does not often hamper clinical use of this drug (6). DDAVP is often used in combination with an antifibrinolytic agent in Europe, but the addition of an antifibrinolytic agent entails the risk of thrombosis (6). In the predialysis period, chronic renal failure patients may develop desmopressin induced water retention which may increase the likelihood of developing congestive heart failure. In patients undergoing coronary artery by-pass surgery, inhibition of WF was suggested to be preferable to its elevation in order to encourage graft patency (6).

CRYOPRECIPITATE: Cryoprecipitate is rich in factor VIII/VWF and may shorten the prolonged bleeding time in uremia (15). The hemostatic response to cryoprecipitate infusion is variable. Some patient with uremic bleeding do not respond to this therapy (14). This is consistent with the current concept that pathogenesis of uremic bleeding is multifaceted. Cryoprecipitate should be reserved for those failing to respond to DDAVP, and for whom DDAVP is contrain- 
dicated. For actively bleeding patients usual dose for cryoprecipitate is 10 bags given over 30 minutes. In one study the nadir value of bleeding time occurred one to 12 hours after infusion (14). Same as with other blood products this treatment carries the risks of transmitting infections, allergic or rarely anaphylactic reactions and serologic incompatibility due to red cell isoagglutinins(14).

CONJUGATED ESTROGENS: Conjugated estrogens were introduced recently in the management of uremic bleeding. Patients who are in need of prolonged hemostatic competence, because of gastrointestinal or major surgery, conjugated estrogens should be considered. Among the compounds of conjugated estrogens $17 \mathrm{~B}$-estradiol is found to be the most active component in correcting prolonged bleeding time in uremic rats (12). The dissociation between the short plasma estrogen half-life (a few hours) and the long lasting effect (weeks) is remarkable. This suggests that the effect of estrogens on primary hemostasis in uremia is mediated by a receptor mechanism. Estrogens enter the cell and bind high affinity receptor proteins on the cytosol, then estrogen protein complex is translocated into the cell nucleus with subsequent induction of specific mRNA and certain specific but unknown proteins (12). Platelets do not possess specific receptors for estrogens (12). There are some evidence that endothelial cells and white blood cells have estrogen receptor. The mechanism of correction of uremic bleeding tendency wich estrogen treatment is still unclear. Conjugated estrogen infusion $0.6 \mathrm{mg} / \mathrm{kg} /$ day for 5 consecutive days is the current recommended regimen. With this protocol the initial effect in decreasing bleeding time is seen 6 hours after the first dose and maximum effect can be achieved in 5-7 days, and bleeding time usually returns to pretreatment level in 2-3 weeks. Because of the delayed onset of action, this treatment is usually underestimated and not much used in some units. Whenever prolonged bleeding control is needer conjugat ed estrogens should be started at the same time with rapidly acting agents like DDAVP, and cryoprecipitate. Oral conjugated estrogens at a dose of $50 \mathrm{mg}$ daily for seven days was shown to be effective but the length of effect is shorter, bleeding time can become prolonged within 4 days after the treatment (16).

ANTIFIBRINOLYTIC AGENTS: Epsilon aminocaproic acid and tranexaminic acid have proved to be extraordinarily effective in achieving oral hemostasis; the newer drug, tranexaminic acid is more potent (6). tients undergoing tooth extractions and minor oral surgery may benefit from these drugs. Both drugs inhilbit plasminogen activation and, to a lesser degree, plasmin. The unwanted effect of this antifibrinolytic therapy is the development of thrombi in areas other than the target site. Epsilon aminocaproic acid has been known to cause thrombosis in the glomerular capillaries renal pelvis and ureters of patient with upper urinary tract bleeding. This agent should not be used to treat hematuria of upper urinary tract origin. Tranexamic acid is contraindicadet in patients with subarachnoid hemorrhage, because it may cause cerebral edema and infarction (6).

TOPICAL HEMOSTATICS: In uremic patients, topical hemostatic agents can be both used for exterior wounds or during surgery. They can be used in conjunction with systemic antifibrinolytic therapy to achieve immediate hemostasis at a wound site. Adsorbable collagen hemostat $(\mathrm{ACH})$ is a faster and more effective agent than thrombin, gelatin foam, or oxidase cellulose. The rapid hemostatic effect of ACH is mediated by its interaction with platelets at the injury site. This bovine collagen product sticks firmly to the bleeding surface, and its fibrillar structure provides a mesh in which platelets become trapped. As platelets interact with the collagen fibrils, they undergo the release phenomenon, triggering further aggregation and production of fibrin (6). ACH has been 
reported to achieve effective local hemostasis during surgery in patients receiving heparin or aspirin and in patients with coagulation factor deficiencies (6). ACH creates a slightly more intense and longer-lasting inflammatory response than normal but doesn't delay the rate or quality of wound healing. The collagen metarial is resorbed in less than a week (6).

PLATELET TRANSFUSION: Platelet transfusion is advocated only in uncontrolled hemorrhage in uremic patients. Shortly after entering the uremic environment, platelets become dysfunctional, so platelet transfusion should be used only in combination with DDAVP, cryoprecipitate and packed red blood cells (16).

In most cases, however, none of these measures are necesary if dialysis is adequate. Being unduly aggressive in correcting prolonged bleeding time may at times result in clotting of vascular accesses of the dialysis patients, because there is already an increased likelihood of clotting of the dialysis access perioperatively due to decreased flow because of the hypotension associated with anesthesia.

\section{PEFERENCES}

1. Remuzzi G.Bleeding disorders in uremia : $P a-$ thophysiology and treatment. Adv Nephrol. $1989 ; 18: 171$ 86.

2. Rizzo RJ, Tilney NL. Renal dysfunction, special problems in perioperative care. In: Wilmore DW, Brennan MF, Harken AH, et al, eds. Care Of The Surgical Patient. New York: Scientific American, Inc ; 1993 : 10-11.

3. Lohr JW, Scwab SJ. Minimizing hemorrhagic complications in dialysis patients. I Am Soc Nephrol. $1991 ; 2$ (5) : 961-75.
4. Handing RI. Bleeding and thrombosis. In: Wilson JD, Braunwald E, Isselbacher KJ, et al, eds. Harrison's Principles of Internal Medicine. 12th ed. New York: McGraw Hill, Inc ; 1991 : 348-353.

5. Benigni A, Boccardo P, Galbusera $M$, et al. Reversible activation defect of the platelet glycoprotein IIb-IIIa complex in patients with uremia. Am J Kid Dis. 1993 ; 22(5): 66876 .

6. Aledort LM. New approaches to management of bleeding disorders. Hospital Practice. 1989 ; 2 : 207-226.

7. Escolar BG, Cases A, Bastida E, et al. Uremic platelets have a functional defect affecting the interaction of von Willebrand Factor with glycoprotein IIb-IIIa. Blood. 1990 ; 76 : 1336-40.

8. Zwaginga JJ, Ijsseldijk MJW, Beeser-Visser $N$, de Groot PG, Vos J, Sixma JJ. High von Willebrand factor concentration compensates a relative adhesion defect in uremic blood. Blood. $1990 ; 75$ : 1498-508.

9. Carvalho AC. Acquired platelet dysfunction in patients with uremia. Hematol / Oncol Clin North Ame $1990 ; 4$ (1) : 129-143.

10. Vigano G, Remuzzi G. Prevention and therapeutic management of bleeding in dialysis patients. In: Nissenson $A R$, Fine RN, eds. Dialysis Therapy. 2nd ed. St. Llouis / Baltimore: Hanley \& Belfus, Inc ; 1993 : 124-128.

11. Remuzzi G, Perico N, Zoja C, Coma D, Macconi D, Vigona $G$. Role of endothelium derived nitric oxide in the bleeding tendency of uremia. I Clin Invest. 1990; 86 (11): 1768-71.

12. Vigona GV, Zoja C, Corna D, Rossini M, Pusineri F, Garattini S, Remuzzi G. $17 b$ estradiol is the most active component of the conjugated estrogen mixture active on uremic bleeding by a receptor mechanism. I Pharmacol Exp Therap. $1990 ; 252: 344-8$.

13. Somers DL, Sotolongo C, Bertolatus JA. White clot syndrome associated with renal failure. I Am Soc Nephrol. $1993 ; 4: 137-41$.

14. Triulzi DJ, Blumberg N. Variability in response to cryoprecipitate treatment for hemostatic defects in uremia. Yale I Biol Med. $1990 ; 63: 1-7$

15. Schafer AI. Thrombocytopenia and disorders of platelet function. In: Stein JH, Hutton JJ, Kohler PO, et al, eds. Internal Medicine. 4th ed. St Louis: Mosby ; 1994 : 796-9.

16. Eberst ME, Berkowitz LR. Hemostasis in renal disease: pathophysiology and management. Am I Med. 1994; $96: 168-79$.

17. Akpolat T, Ozdemir O, Arik NL, et al. Effect of desmopressin (DDAVP) on protein $C$ and protein $C$ inhibitors in uremia. Nephron. $1993 ; 64: 232-4$. 